\title{
The Impact of the Fracking Boom on Arab Oil Producers
}

\author{
Lutz Kilian*
}

\begin{abstract}
This article makes four contributions. First, it investigates the extent to which the U.S. fracking boom has caused Arab oil exports to decline since late 2008. Second, the article quantifies for the first time by how much the U.S. fracking boom has lowered the global price of oil. Using a novel econometric methodology, it is shown that in mid-2014, for example, the Brent price of crude oil was lower by $\$ 10$ than it would have been in the absence of the fracking boom. Third, the article provides evidence that the decline in Saudi net foreign assets between mid2014 and August 2015 would have been reduced by $27 \%$ in the absence of the fracking boom. Finally, the article discusses the policy choices faced by Saudi Arabia and other Arab oil producers.
\end{abstract}

Keywords: Arab oil producers, Saudi Arabia, Shale oil, Tight oil, Oil price, Oil imports, Oil exports, Refined product exports, Oil revenue, Foreign exchange reserves, Oil supply shock

https://doi.org/10.5547/01956574.38.6.1kil

\section{INTRODUCTION}

The use of hydraulic fracturing (or fracking) in conjunction with horizontal drilling and micro-seismic imaging has made it possible to extract crude oil from rock formations characterized by low permeability. Oil extracted by these techniques is commonly referred to as tight oil or shale oil to differentiate it from crude oil extracted by conventional drilling techniques. To date, commercial shale oil production has been largely limited to the United States. The U.S. oil fracking boom is an example of a technological change in a single industry in one country affecting international trade worldwide. Increased U.S. shale oil production over time has displaced crude oil exports from Arab oil producing countries, both because the United States no longer relies as heavily on crude oil imports from Arab oil producers and because U.S. refineries have increasingly exported refined products such as gasoline or diesel made from domestically produced crude oil, causing other countries to cut back on their crude oil imports as well (see Kilian 2016). Whereas the gains to the U.S. economy of the fracking boom are well understood at this point, little is known about the losses this development has imposed on foreign oil producers. Understanding the implications of the U.S. fracking boom is important not only for policymakers in Arab economies deciding on how best to respond to the tight oil boom, but it also provides a prime example of a well-identified exogenous shock to the terms of trade of primary commodity exporters.

This article quantifies the impact of the U.S. tight oil boom on global oil production, on U.S. imports of crude oil, on U.S. exports of refined products, and on Arab exports of crude oil. ${ }^{1}$ I represent the U.S. tight oil boom as a sequence of exogenous shocks to world oil production. On

1. An excellent nontechnical study of the impact of the tight oil boom on Arab oil producers is Fattouh (2014).

* Department of Economics, 611 Tappan Street, Ann Arbor, MI 48109-1220, USA. E-mail: 1kilian@umich.edu.

The Energy Journal, Vol. 38, No. 6. Copyright (C) 2017 by the IAEE. All rights reserved. 
the basis of a structural econometric model of the global market for crude oil, I construct an estimate of how the price of oil in global markets would have evolved in the absence of this boom. I show that the cumulative effect of the tight oil boom on the Brent price had been building gradually, reaching a peak in mid-2014, before declining in late 2014. Whereas in mid-2014 the Brent price was lower by $\$ 10$ than it would have been in the absence of the fracking boom, by mid-2015 this price differential had fallen to $\$ 5$. My analysis also demonstrates that a very similar price decline would have occurred between July 2014 and January 2015 even in the absence of increased U.S. shale oil production, suggesting that increased shale oil production was not the main cause of this price decline. $^{2}$

I use the difference between the actual and the counterfactual global price of crude oil to quantify the losses in Saudi oil revenue (and hence in Saudi national income) since late 2008 under the maintained assumption that Saudi oil production remained unchanged by the fracking boom. My analysis shows that the cumulative losses in Saudi oil revenue caused by fracking by August 2015 had reached 102 billion dollars. I relate this estimate to the substantial decline in Saudi net foreign assets between mid-2014 and August 2015. I show that the shale oil boom accounts for $27 \%$ (or 24 billion U.S. dollars) of this decline, with the remaining 66 billion dollars reflecting increased oil production by other oil producers, shifts in oil price expectations, and the weakening of the global economy. I make the case that this decline is unsustainable and discuss implications of my analysis for Saudi economic policies in the years to come.

The remainder of the article is organized as follows. In section 2, I review the evolution of crude oil production in the United States and elsewhere, highlighting the contribution of the U.S. fracking boom to global oil production growth. Sections 3 and 4 quantify the extent to which the shale oil boom has reduced Arab oil exports since late 2008, distinguishing between the reduction in U.S. crude oil imports from Arab oil producers and the reduction in Arab oil exports to the rest of the world caused by increased U.S. exports of refined products, as U.S. refiners took advantage of access to comparatively low-cost domestically produced crude oil. In section 5, I study the financial implications of the U.S. fracking boom for Arab oil producers, focusing on Saudi Arabia as the leading example. Building on the analysis in sections 2, 3 and 4, I develop and compare two data-based counterfactuals aimed at estimating the implications of the shale oil boom for the global price of oil and for Saudi Arabia's oil revenues between December 2008 and August 2015. Section 6 relates my preferred estimate of these effects to the dramatic decline in Saudi net foreign assets since June 2014 and discusses the policy implications for Saudi Arabia in particular. The concluding remarks are in Section 7.

\section{RECENT CHANGES IN OIL PRODUCTION IN THE UNITED STATES AND ELSEWHERE}

Only a few years ago, a common view among pundits was that world oil production would no longer be able to keep up with growing oil consumption needs. An extreme version of this

2. The construction of the counterfactual rules out an endogenous response of Saudi oil production to the U.S. shale oil boom, consistent with the conclusion of Baumeister and Kilian (2016b) and Kleinberg et al. (2016) that there is no documented evidence of such a policy response. In fact, the data show no apparent reaction by Saudi Arabia until March 2015, when Saudi oil production increased slightly. If this increase was a Saudi policy shift at all, then this shift was in response to falling oil prices after June 2014, not in response to the rise in shale oil production since late 2008. Moreover, given the recursive nature of the counterfactual, even if some of the price decline in 2014 had been caused by the effects of the U.S. shale oil boom, the potential endogeneity of the alleged Saudi oil production response starting in March 2015 may effectively be ignored, because only the last six months of the 82 months, for which I construct the counterfactual, could possibly be affected by any Saudi policy response.

Copyright (C) 2017 by the IAEE. All rights reserved. 


\section{Figure 1: Crude Oil Production Disaggregated}
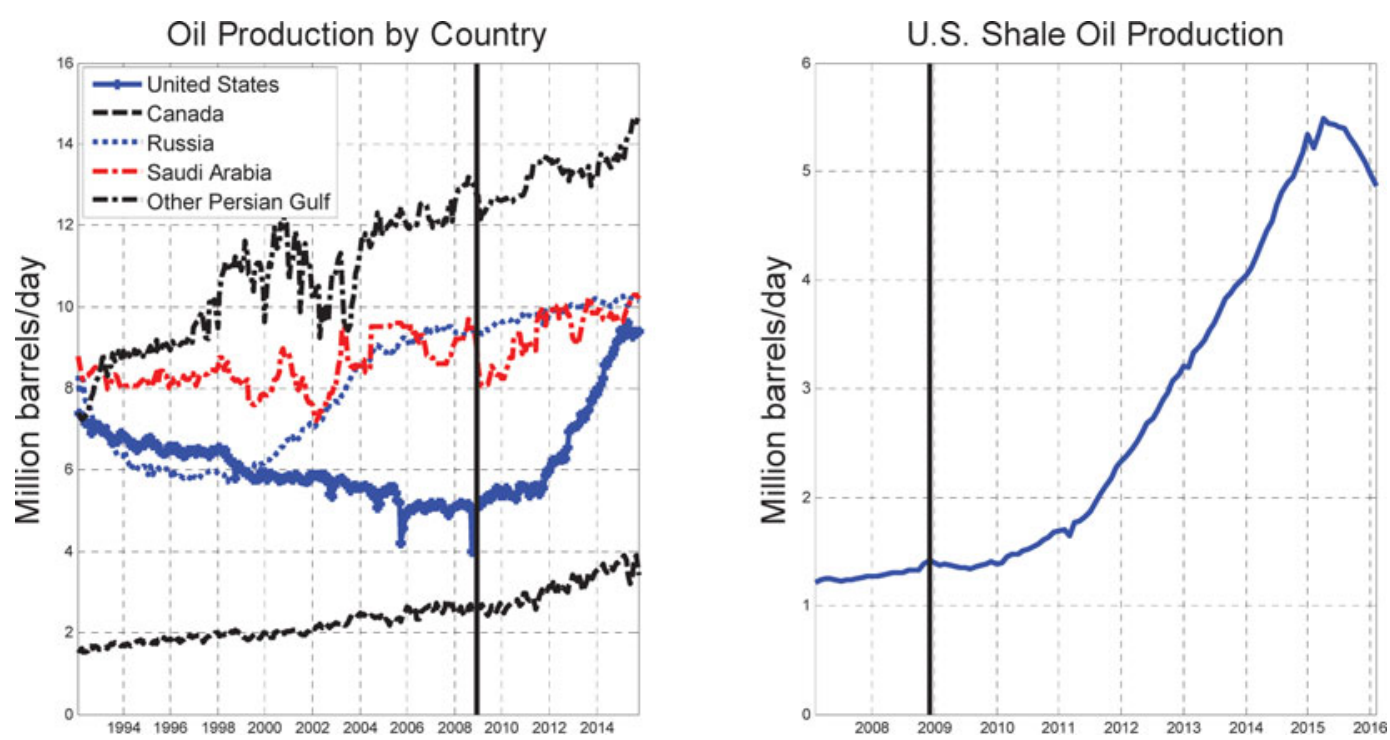

Notes: The international data are from U.S. Energy Information Administration (2015). The production data are for crude oil and lease condensate, but exclude natural gas plant liquids. The vertical line marks the reversal in the long-term decline of U.S. oil production in November 2008. The shale oil production data are obtained from U.S. Energy Information Administration (2016) by adding crude oil production in the seven largest U.S. shale oil plays, which account for the bulk of U.S. shale oil production.

skepticism was embodied in the peak oil hypothesis which asserted that global oil production had permanently peaked by 2007 or that the peak was imminent. ${ }^{3}$ Although economists tend to be skeptical of the peak oil hypothesis for reasons discussed in Holland (2008, 2013), it was readily apparent at the time that many traditional oil fields were in decline and that the prospects for discovering more crude oil in regions not ridden with civil strife were diminishing. Thus, even granting that high oil prices driven by strong demand for oil tend to provide strong incentives for expanding future oil production, as of 2007, nothing in past experience guaranteed that the supply response to rising oil prices would be adequate or that it would occur in a timely manner.

As the left panel of Figure 1 shows, with the benefit of hindsight, these concerns were unwarranted. Not only did the U.S. fracking boom reverse the long-standing decline in U.S. crude oil production, but Canadian production of unconventional crude oil from oil sands soared and Russian oil production reached unprecedented levels. At the same time, both Saudi Arabian and other Persian-Gulf production growth, which seemed to have levelled off after 2005, accelerated again. This surge in oil production was more than enough to offset the decline in crude oil production in other countries. Table 1 shows an increase in global oil production of 6.17 million barrels per day (mbd) between November 2008 and September 2015, corresponding to an average rate of increase of $1.16 \%$. Average growth accelerated to 2.63\% between June 2014 and September 2015. Table 1 dispels the notion that fracking in the United States alone has been responsible for this

3. For example, an IMF study by Benes et al. (2015), using data up to 2009, predicted a near doubling of the price of oil over the coming decade based on the view that geological constraints would win out over technological improvements in conserving oil use and in oil extraction. 
Table 1: Changes in Crude Oil Production

\begin{tabular}{|c|c|c|c|c|}
\hline \multirow[b]{2}{*}{ Oil producers } & \multicolumn{2}{|c|}{ 2008.11-2015.9 } & \multicolumn{2}{|c|}{ 2014.6-2015.9 } \\
\hline & $\begin{array}{c}\text { Change in million } \\
\text { barrels/day }\end{array}$ & $\begin{array}{l}\text { Average percent } \\
\text { change }^{\mathrm{a}}\end{array}$ & $\begin{array}{l}\text { Change in million } \\
\text { barrels/day }\end{array}$ & $\begin{array}{l}\text { Average percent } \\
\text { change }^{\mathrm{a}}\end{array}$ \\
\hline World & 6.17 & 1.16 & 2.76 & 2.63 \\
\hline Saudi Arabia & 1.23 & 1.86 & 0.50 & 3.78 \\
\hline Other Persian Gulf & 1.97 & 2.08 & 1.14 & 6.05 \\
\hline Iran & -0.80 & -3.13 & 0.15 & 3.49 \\
\hline Iraq & 2.07 & 9.12 & 1.10 & 21.63 \\
\hline Kuwait & 0.06 & 0.37 & -0.10 & -2.88 \\
\hline Qatar & 0.36 & 3.90 & -0.02 & -0.78 \\
\hline UAE & 0.25 & 1.39 & 0 & 0 \\
\hline Russia & 0.79 & 1.17 & 0.06 & 0.41 \\
\hline Canada and United States & 5.03 & 7.24 & 0.57 & 3.44 \\
\hline Canada & 0.73 & 3.48 & -0.14 & -2.93 \\
\hline United States & 4.30 & 8.89 & 0.71 & 5.91 \\
\hline
\end{tabular}

Source: U.S. Energy Information Administration (2105), Monthly Energy Review.

Notes: 2008.11 marks the reversal in the long-term decline of U.S. oil production. 2014.6 marks the end of a long period of relative price stability in the market of crude oil, before the recent collapse of the price of crude oil (see Baumeister and Kilian 2016b)

a at annualized rates

surge. Although the United States was responsible for the bulk of the oil production increase, accounting for an extra $4.3 \mathrm{mbd}$ over the last seven years, there also have been notable production increases in Iraq (2.07 mbd), Saudi Arabia (1.23 mbd), Russia (0.79 mbd) and Canada (0.73 mbd) that were unrelated to the fracking boom.

The evolution of U.S. oil production in particular is remarkable, given the long-standing decline in U.S. oil production that began in the early 1970s and was only briefly reversed by the development of the Alaskan oil fields in the late 1970s. The vertical line in the left panel of Figure 1 refers to the date of November 2008, which marks the reversal of this trend. It can be shown that this reversal is largely due to the U.S. fracking boom. The right panel of Figure 1 plots the sum of crude oil production at the Bakken, Eagle Ford, Haynesville, Marcellus, Niobrara, Permian, and Uttica shale oil plays. These seven regions account for $92 \%$ of U.S. domestic shale oil production growth. Between November 2008 and September 2015, U.S. shale oil production increased by approximately $3.82 / 0.92=4.15$ million barrels/day (mbd), which roughly matches the entry of 4.30 mbd for the change in total U.S. crude oil production in the first column of Table 1. Thus, throughout this article, I will treat November 2008 as the beginning of the fracking boom.

\section{QUANTIFYING THE DECLINE IN U.S. CRUDE OIL IMPORTS FROM ARAB PRODUCERS}

The U.S. oil sector is governed by the following identity, which describes the composition of the total quantity of crude oil used by the economy: $Q_{t}+M_{t}-X_{t}=C_{t}-\Delta I_{t}$, where $Q_{t}$ is domestic crude oil production, $M_{t}$ is U.S. crude oil imports, $X_{t}$ is U.S. crude oil exports, $C_{t}$ is the consumption of crude oil, which refers to crude oil used by U.S. refineries to produce refined products such as gasoline or diesel for domestic consumption or for export, and $\Delta I_{t}$ denotes the change in crude oil inventories. 


\section{Figure 2: The U.S. Crude Oil Sector, 1973.1-2015.11}


Notes: The raw data are from U.S. Energy Information Administration's (2015). Total oil use is defined as: Domestic Production of Crude Oil + Crude oil imports - Crude oil exports.

The left panel of Figure 2 illustrates how U.S. domestic oil production, crude oil imports and exports of crude oil have evolved since the 1970s. Three facts stand out. First, as already noted, following a secular decline in U.S. oil production, U.S. oil production sharply accelerated in late 2008, reflecting the fracking boom. Second, historically crude oil imports have been rising during economic expansions and falling during economic downturns. This pattern changed in 2005, even before the fracking boom, when the U.S. economy learned to make do with less crude oil during an economic expansion amidst high and rising oil prices (see also Baumeister and Kilian 2017). The decline in crude oil imports accelerated during the fracking boom, when increased domestic shale oil production lowered the U.S. price of oil compared with the global price of oil, reducing U.S. demand for high-cost crude oil imports. The reason for the comparatively low price of shale oil was a glut of light sweet crude oil in the central United States that reflected transportation bottlenecks within the United States as well as a ban on U.S. crude oil exports (see Kilian 2016). There have been some exemptions from this ban, notably for oil exports to Canada, but overall this restriction has been binding. As a result, U.S. crude oil exports have remained negligible throughout most of this sample. Only in 2014 and 2015 U.S. oil exports increased somewhat, as the Obama administration allowed for more flexibility in the interpretation of the law governing U.S. oil exports. As of December 2015, Congress passed a law lifting the oil export ban, but that policy shift is not yet reflected in the data in Figure 2.

The right panel of Figure 2 quantifies the total use of crude oil by the U.S. economy, computed as $Q_{t}+M_{t}-X_{t}$. In quantifying the importance of oil imports for the U.S. economy, it is useful to express U.S. crude oil imports as a share of the amount of crude oil used by the U.S. economy. ${ }^{4}$ The left panel of Figure 3 shows the evolution of the share of U.S. crude oil imports

4. This approach controls for fluctuations in the size of the U.S. economy and for slow-moving changes in the energy efficiency of the U.S. economy. During a recession, for example, all else equal, both the use of crude oil by the economy 
Figure 3: Crude Oil Imports from Selected Countries as a Percent Share of U.S. Oil Use
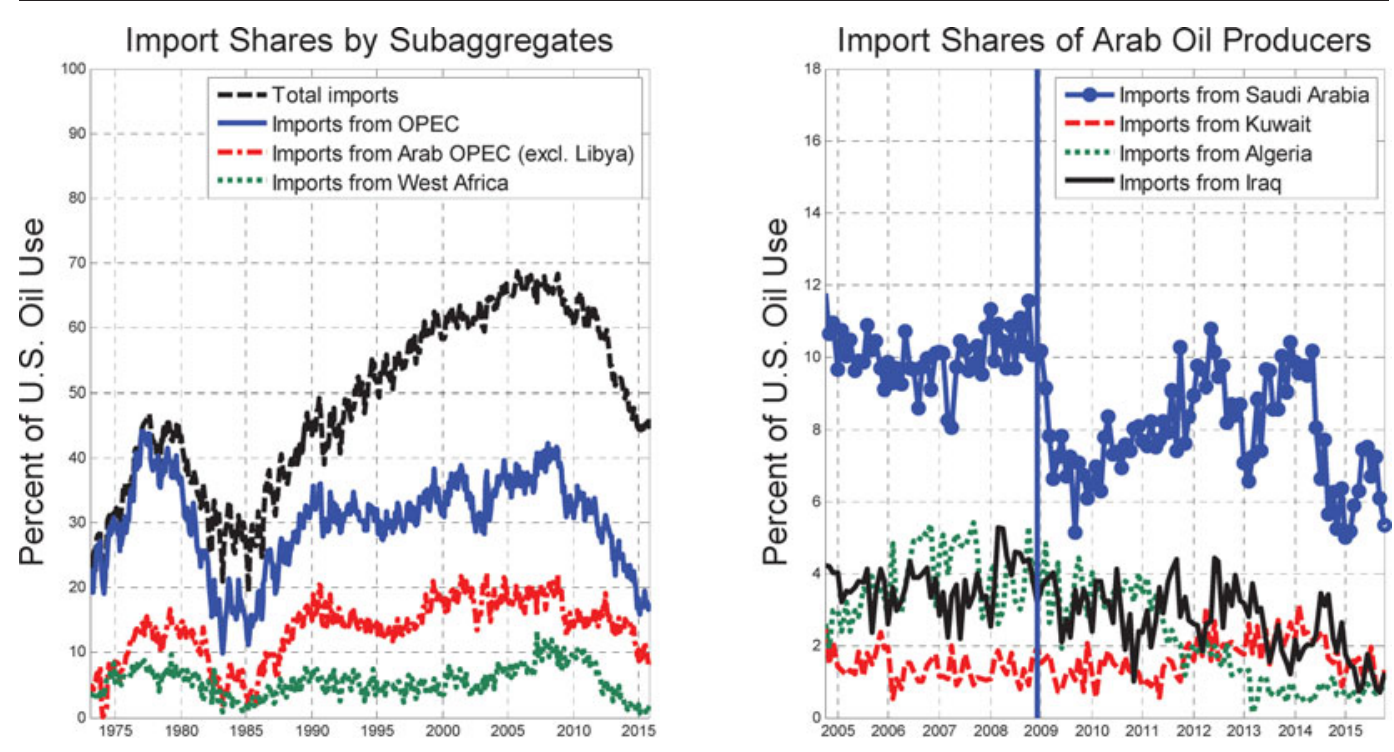

Notes: The raw data are from U.S. Energy Information Administration (2015). The vertical line marks the reversal in the long-term decline of U.S. oil production in November 2008.It also coincides with the drop of the share of Saudi oil imports in the U.S. use of oil.

from the rest of the world as well as the share of U.S. crude oil imports from OPEC, from Arab OPEC (defined as Algeria, Iraq, Kuwait, and Saudi Arabia for our purposes), and from West Africa (Nigeria, Angola). ${ }^{5}$ The overall import share declined from a peak of almost $70 \%$ in the mid-2000s to about $45 \%$ in 2015 . This pattern is also found for OPEC oil imports and its components. By 2015 crude oil imports from West Africa fell to near zero. West African crudes are in direct competition with domestically produced light sweet crude oil in the United States. As U.S. refiners along the East Coast found ways of substituting shale oil (or lower priced conventional light sweet crude oil from domestic sources) for these imports, West African crudes were almost entirely displaced. Crude oil imports from Arab OPEC as well fell from about $20 \%$ of U.S. oil use as recently as 2008 to under $10 \%$ in 2015 . The reason presumably was that these crudes no longer could compete with the low price of domestically produced U.S. crude oil and U.S. imports of heavy Canadian crudes (see Kilian 2016).

The right panel of Figure 3 traces the import shares of four Arab oil producers before and after November 2008, which marks the beginning of the fracking boom (see Figure 1). We are interested in whether there are important changes in the dependency of the U.S. economy on oil imports from these countries. Figure 3 shows a striking drop in the share of U.S. oil imports from

and its oil imports would be expected to fall without affecting the oil import share. In contrast, if the fracking boom displaces crude oil imports from Arab oil producers, this should be reflected in a reduction in the share of U.S. imports from Arab countries in the oil used by the U.S. economy.

5. I approximate crude oil imports from these countries by petroleum imports under the assumption that U.S. product imports from Arab countries are zero. This assumption can be verified for selected dates using data in the EIA's database for U.S. crude oil imports at the company level. Figure 3 excludes Libya from the Arab oil producers because Libyan oil exports in recent years are driven primarily by political events in Libya. The UAE and Qatar are excluded, because the EIA does not provide monthly data for U.S. imports from these countries, given their small size.

Copyright (C) 2017 by the IAEE. All rights reserved. 
Saudi Arabia after November 2008. After some fluctuations, the Saudi share reaches near 5\% in 2015, compared with about $10 \%$ initially. Figure 3 shows a steady decline in the share of U.S. oil imports from Algeria (another producer of light sweet crude oil not unlike the West African oil producers) as well. The share of U.S. oil imports from Iraq also declines over time. The higher volatility of the latter share is likely explained by political constraints on Iraqi oil production more than the fracking boom. Only the share of oil imports from Kuwait has remained largely stable.

How quantitatively important is the reduction in U.S. market share for Arab oil exporters? One simple measure of the displacement of Arab oil exports to the United States by domestically produced shale crude oil is the amount of crude oil (measured in millions of barrels per day) that the United States would have imported from Saudi Arabia, Kuwait, Algeria, and Iraq, respectively, if, after November 2008, the share of U.S. imports from those countries had remained constant at its average value between September 2004 and November 2008. ${ }^{6}$ As discussed in section 4, there are, however, additional effects of the fracking boom on Arab oil exports that arise from the displacement of non-U.S. crude oil imports. It is useful to discuss the estimation of these additional effects, before presenting numerical estimates for the combined reduction in Arab oil exports caused by the fracking boom.

\section{QUANTIFYING THE DISPLACEMENT OF ARAB OIL EXPORTS TO THE REST OF THE WORLD}

Given the U.S. crude oil export ban, very little of the shale oil production generated by the fracking boom was exported. It might seem that this production would not have mattered for Arab oil exports beyond the reduction in U.S. crude oil imports. The glut of light sweet crude oil in the central United States that emerged during the fracking boom, however, depressed the price of domestically produced crude oil, allowing U.S. refiners access to comparatively low-priced domestic crude oil. Refiners seized this opportunity to convert the crude oil to refined products such as gasoline and diesel fuel to be sold at competitive prices in Europe and Latin America. These exports of refined products effectively circumvented the ban on crude oil exports. To the extent that countries in the rest of the world that bought these refined products no longer needed to import as much crude oil for their refineries as before, this trade in refined products reduced the demand for Arab oil exports in the rest of the world, adding to the costs of the fracking boom to Arab oil producers (see Kilian 2016).

6. This benchmark is reasonable in that the Saudi share, for example, remained remarkably stable over this period (see Figure 3). Disregarding earlier data in computing this share helps avoid variation in the share caused by exogenous events such as the 2003 Iraq War. In the absence of alternative explanations of the variation in Arab oil exports, the difference between this counterfactual path of Arab oil exports and the observed path of Arab oil exports to the United States can be interpreted as the loss in Arab oil exports caused by the fracking boom. Clearly, the assumption that all of the variation in the share of Arab imports can be attributed to the fracking boom may be questioned. For example, there could be alternative explanations of the disproportionate drop in the U.S. import share from Saudi Arabia between 2009 and 2011. Moreover, there are reasons to believe that U.S. imports from Saudi Arabia are less sensitive to the shale oil boom than other oil imports, because some U.S. refineries have been designed specifically for Saudi medium-density crude and because Saudi crude oil faces little direct competition form light sweet shale oil (also see Kilian 2016). Finally, one could make the case that oil producers responding to a decline in the global price of oil triggered by reduced U.S. oil use would reduce their oil production proportionately to their share in global oil production, in which case the import share would not remain constant over time, but may actually fall in response to a decline in the use of oil by the U.S. economy. For now we put these concerns aside. The realism of the working assumption of constant import shares will be assessed in section 5 by confronting counterfactual oil price estimates based on this assumption with extraneous evidence. 
Figure 4: Quantifying the Displacement of Other Crude Oil Producers' Exports Caused by U.S. Exports of Refined Products
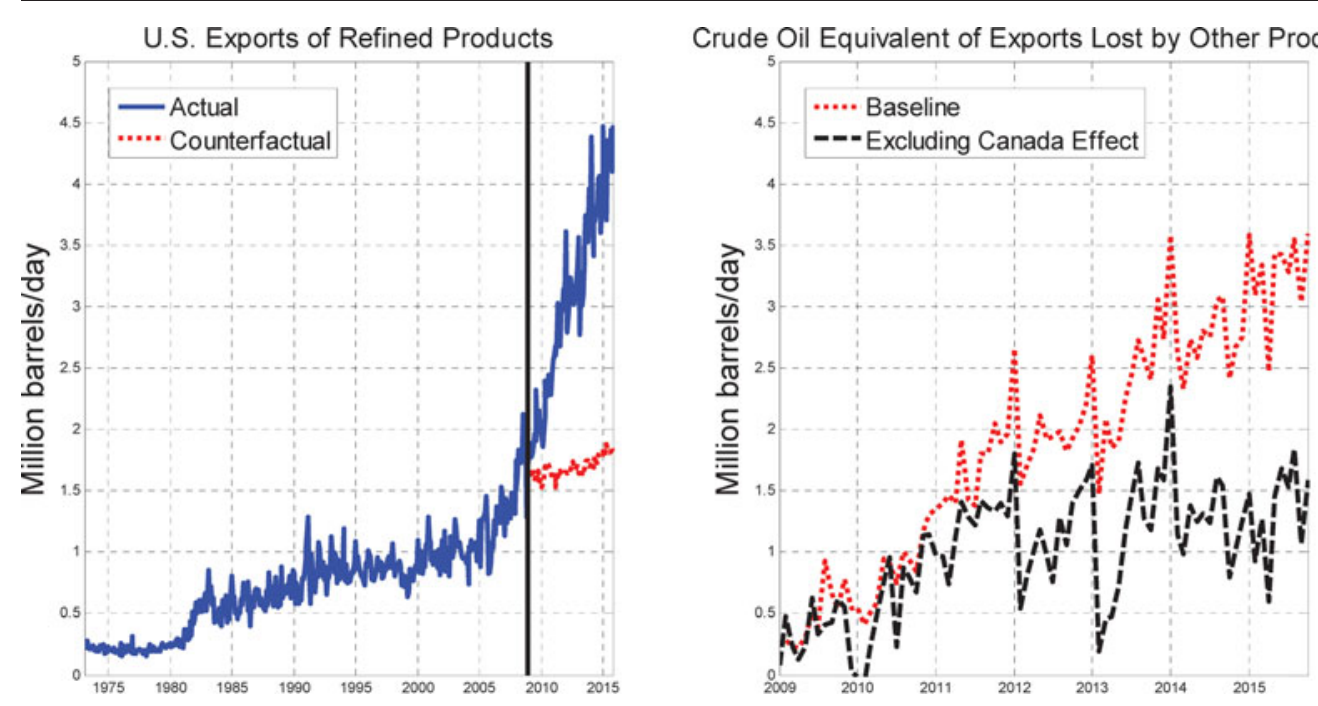

Notes: Based on data from U.S. Energy Information Administration (2015). The vertical line marks the reversal in the longterm decline of U.S. oil production in November 2008. The counterfactual is constructed by assuming that the share of U.S. exports of refined products in total use of oil by the U.S. economy remains constant at its level in November 2008 . The crude oil equivalent is computed by multiplying the shortfall of exports computed in the left panel by 1.3548 . This conversion factor is based on the fact that U.S. refineries in 2014 on average produced 12 gallons of diesel and 19 gallons of gasoline (for a total of 31 gallons of refined product) from 42 gallons (one barrel) of crude oil, according to the EIA. The Canada effect refers to increased imports of crude oil from Canada in excess of the reduction of U.S. imports of crude oil from Mexico and from Venezuela. To isolate U.S. exports of refined products made from domestic crude oil, this effect must be corrected for.

The left panel of Figure 4 shows a surge in U.S. exports of refined products in recent years. Assuming that the share of the crude oil equivalent of U.S. product exports in the crude oil used by the U.S. economy remained constant at its November 2008 value for the remainder of the sample, one can infer how exports of refined products would have evolved in the absence of the fracking boom starting in late 2008. The difference between the path of actual and counterfactual U.S. product exports provides a rough measure of the magnitude of the implied reduction in Arab oil exports to the rest of the world caused by the shale oil boom. The right panel of Figure 4 expresses this loss in terms of its crude oil equivalent. ${ }^{7}$

This baseline estimate of the Arab crude oil exports lost to U.S. refined product exports, however, ignores the fact that rising Canadian exports of crude oil allowed the United States to export more refined products than otherwise would have been possible. Imports of heavy crudes from Canada in particular appear to have displaced U.S. imports of heavier crudes from Mexico and Venezuela with the latter countries' import shares after late 2005 steadily falling from $9 \%$ each

7. The crude oil equivalent is computed by multiplying the shortfall of product exports computed in the left panel by 1.3548. This conversion factor is based on the fact that U.S. refineries in 2014 on average produced 12 gallons of diesel and 19 gallons of gasoline (for a total of 31 gallons of refined product) from 42 gallons (one barrel) of crude oil, according to the U.S. Energy Information Administration. Assuming an average mix of diesel and gasoline, this implies a conversion factor of $42 / 31=1.3548$. 


\section{Figure 5: Direct and Indirect Crude Oil Export Losses Combined}

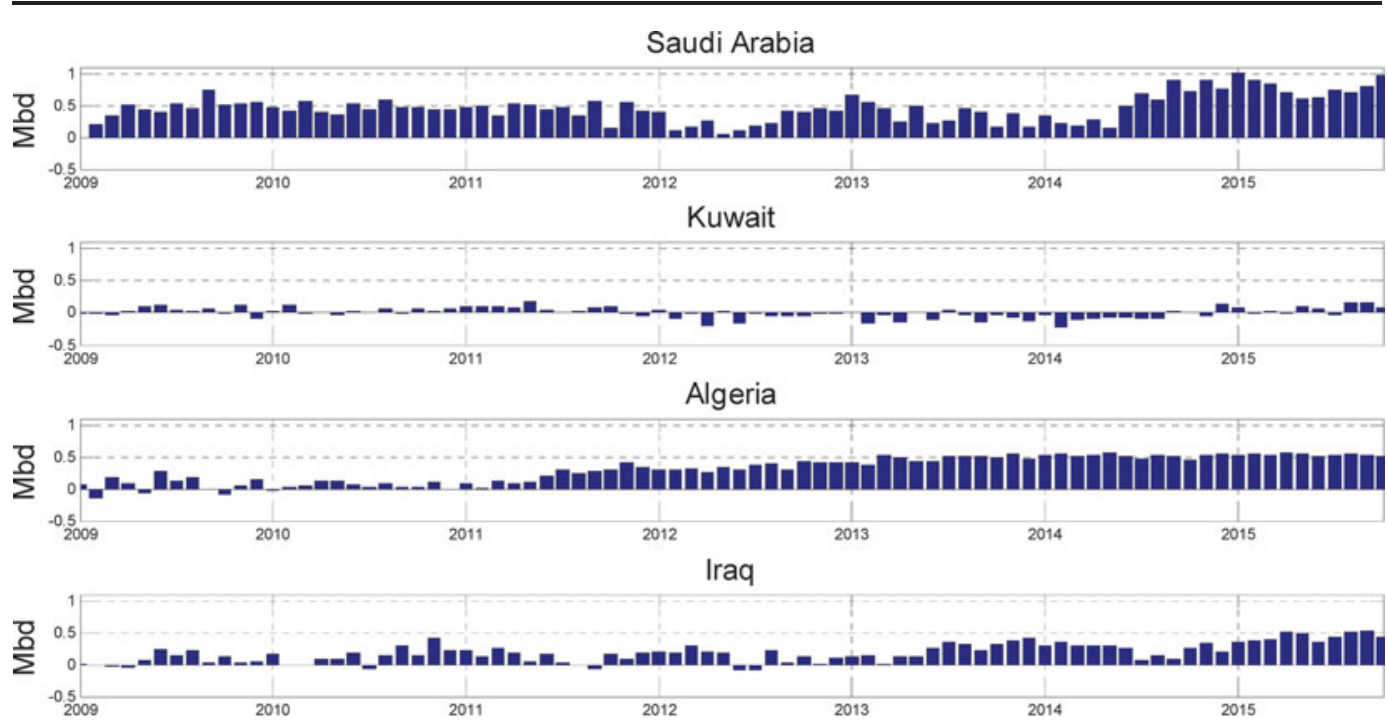

Notes: The estimates are obtained by summing the direct loss arising from the fact that the United States reduced its imports from Arab oil producers given the increased availability of shale oil, and the indirect loss arising from the loss of Arab crude oil export markets, as U.S. refineries increase their exports of refined products, including the adjustment for net gains in crude oil imports from Canada, Mexico and Venezuela.

to about $4 \%$ and Canada's share steadily rising from $15 \%$ to $21 \%$ over the same period. ${ }^{8}$ Thus, the increase in U.S. oil imports from Canada exceeds the combined reduction in U.S. oil imports from Mexico and in U.S. oil imports from Venezuela. It would be misleading to attribute the resulting product exports to the fracking boom.

Subtracting the net increase in crude oil imports from Canada, Mexico and Venezuela from the baseline export loss series in the right panel of Figure 4 tends to reduce the estimate of the oil export losses of the rest of the world substantially. I take the latter series as the benchmark when assessing the role of the fracking boom in driving up U.S. refined product exports. In quantifying the Arab oil export losses caused by the U.S. exports of refined products, for simplicity, I assume that the total loss of exports to the rest of the world (measured as the crude oil equivalent of increased U.S. product exports) can be apportioned based on the average share of each country's oil production in oil production in the world excluding the United States.

Figure 5 combines for each Arab oil producer the reduction in oil exports to the United States discussed in section 3 and the reduction in oil exports to the rest of the world estimated in section 4. For Saudi Arabia, Algeria and Iraq, there is a tendency for the export losses expressed in million barrels of crude oil per day to increase over time. In the case of Saudi Arabia, the combined losses reach one million barrels per day in 2014; Algeria reaches 0.5 million barrels per day in 2013 and Iraq in 2015. Only Kuwait has been largely unaffected with no pronounced tendency for increased export losses over time. Aggregating these estimates across the four countries under consideration, Arab oil export losses over time reached a maximum of $5.3 \mathrm{mbd}$. This indirect

8. These estimates were obtained by multiplying U.S. petroleum imports from these countries by the country-specific share of crude oil in these imports obtained from October 2014 data in the Energy Information Administration's company level reports. 
estimate is somewhat higher than the direct estimate of the increase in U.S. shale oil production in section 2 .

\section{HOW MUCH OIL REVENUE DID ARAB OIL PRODUCERS LOSE?}

So far we have quantified the physical oil exports foregone by Arab oil producers as a result of the surge in U.S. tight oil production (measured in barrels per day). An equally important question is how large the financial losses have been in U.S. dollars. For concreteness, my discussion in this section focuses on Saudi Arabia. Answering this question involves constructing a counterfactual for the price of crude oil based on a structural model of the global oil market. A natural counterfactual is how different the price of crude oil would have been, if all oil producers other than the United States had maintained their observed oil production levels, but the U.S. fracking boom had never happened. This counterfactual level of global oil production may be constructed either by lowering actual global oil production by the amount of reduced U.S. crude oil imports from the rest of the world and by the crude oil equivalent of the expansion of U.S. refined product exports that occurred in response to the shale oil boom, or, alternatively, by subtracting a direct estimate of U.S. shale oil production. Given a suitable structural model of the oil market, one may then infer the sequence of flow supply shocks required to produce this path of oil production after November 2008, holding constant the remaining structural shocks in the model. If this counterfactual shock sequence does not differ systematically from historical shock sequences, we may feed it back into the structural model to simulate how the price of oil would have evolved under the counterfactual. Based on this counterfactual price sequence, the implied increase in Saudi revenues may be computed as $Q_{t}^{\text {Saudiactual }}\left(P_{t}^{\text {counterfactual }}-P_{t}^{\text {actual }}\right)$, where $Q_{t}^{\text {Saudiactual }}$ denotes the observed level of Saudi oil production in month $t$ and $P_{t}^{\text {counterfactual }}-P_{t}^{\text {actual }}$ denotes the difference between the actual dollar price of oil and the dollar price of oil obtained under this counterfactual. ${ }^{9}$

\subsection{The Structural Model of the Global Oil Market}

The counterfactual price of oil is constructed with the help of a structural vector autoregressive (VAR) model of the global market for crude oil (see, e.g., Kilian and Murphy (2014); Kilian and Lee (2014); Baumeister and Kilian (2014, 2016a)). This structural model includes four variables: (1) the growth in global crude oil production, (2) an updated measure of cyclical fluctuations in global real economic activity originally proposed by Kilian (2009), (3) the log of the real price of crude oil (obtained by deflating the U.S. refiners' acquisition cost for crude oil imports by the U.S. CPI), and (4) the change in above-ground global crude oil inventories measured by a suitable proxy. We follow the literature in estimating the model at monthly frequency using seasonal dummies and 24 autoregressive lags. Abstracting from the pre-sample observations, the estimation period starts in 1975.2. The model is re-estimated on data extending to August 2015, as described in Kilian and Lee (2014).

9. There are several potential caveats to keep in mind. First, this thought experiment is based on the premise that increased U.S. shale oil production was entirely due to exogenous oil supply shocks rather than being caused by oil demand shocks. This assumption is consistent with the view that in the absence of technological innovation, the shale oil boom would not have taken place, but it makes no allowance for effects working through oil price expectations. Second, the counterfactual effectively postulates that Saudi Arabia would have been unable or unwilling to increase its oil production in the absence of the fracking boom. 
The structural shocks are identified based on a combination of sign restrictions and bounds on the short-run price elasticities of oil demand and oil supply. The key identifying assumptions are restrictions on the signs of the impact responses of the four observables to each structural shock. There are four structural shocks. First, conditional on past data, an unanticipated disruption in the flow supply of oil causes oil production to fall, the real price of oil to increase, and global real activity to fall on impact. Second, an unanticipated increase in the flow demand for oil (defined as an increase in oil demand for current consumption) causes global oil production, global real activity and the real price of oil to increase on impact. Third, a positive speculative demand shock, defined as an increase in inventory demand driven by expectations shifts not already captured by flow demand or flow supply shocks, in equilibrium causes an accumulation of oil inventories and raises the real price of oil. The accumulation of inventories requires oil production to increase and oil consumption to fall (associated with a fall in global real activity). Finally, the model also includes a residual demand shock designed to capture idiosyncratic oil demand shocks driven by a myriad of reasons that cannot be classified as one of the first three structural shocks. ${ }^{10}$ Like all sign-identified structural VAR models, this model is set-identified and does not yield a unique solution. I follow Kilian and Lee (2014) in selecting the unique model that comes closest to a one-month price elasticity of oil demand of -0.26 , among all admissible solutions of the model (see Kilian and Murphy 2014; Coglianese et al. 2017). ${ }^{11}$

Figure 6 shows how much shocks to the flow demand for oil, to the flow supply of oil and to speculative (or storage) demand driven by oil price expectations have contributed cumulatively to the evolution of the real price of oil, according to the model estimates. The estimates confirm that all three shocks contributed to the decline in the real price of oil since June 2014 rather than the oil supply shock alone, which is broadly consistent with the conclusions of Baumeister and Kilian (2016b) using an alternative methodology. ${ }^{12}$

\subsection{The Counterfactual Level of World Oil Production}

Our main interest in this article is in the sequence of flow supply shocks in the structural model. Given a pre-specified counterfactual path of global oil production, we may infer the sequence of flow supply shocks required to produce this path of oil production after November 2008, holding constant the remaining structural shocks in the model. Similar techniques are discussed in Waggoner and Zha (1999) and Baumeister and Kilian (2014). Knowledge of this sequence of flow supply shocks then allows us to determine how much higher the price of oil would have been under this

10. In addition to these static sign restrictions, the model imposes the dynamic sign restriction that structural shocks that raise the price of oil on impact do not lower the real price of oil for the first 12 months following the shock. The rationale for this restriction is that an unexpected flow supply disruption would not be expected to lower the real price of oil within the same year nor would a positive flow demand or speculative demand shock. Finally, the model imposes the restrictions that the impact price elasticity of oil supply is close to zero and that the impact price elasticity of oil demand cannot exceed the long-run price elasticity of oil demand, which conventional estimates put at -0.8 .

11. These are the only studies in the literature that estimate the price elasticity of demand explicitly accounting for storage behavior and for the endogeneity of price and quantity. This makes them more credible than earlier studies that do not, resulting in elasticity estimates that are biased toward zero. Other recent studies have obtained even larger estimates of the short-run price elasticity of oil demand ranging from -0.35 to -0.41 using alternative structural models, but the latter studies do not account for storage and are based on lower frequency data (see, e.g., Serletis et al. 2010; Bodenstein and Guerrieri 2012; Baumeister and Peersman 2013).

12. Estimates of the responses of each model variable to each oil demand and supply shock are shown in Appendix A. 
Figure 6: Cumulative Effect of Oil Demand and Oil Supply Shocks on the Real Price of Oil

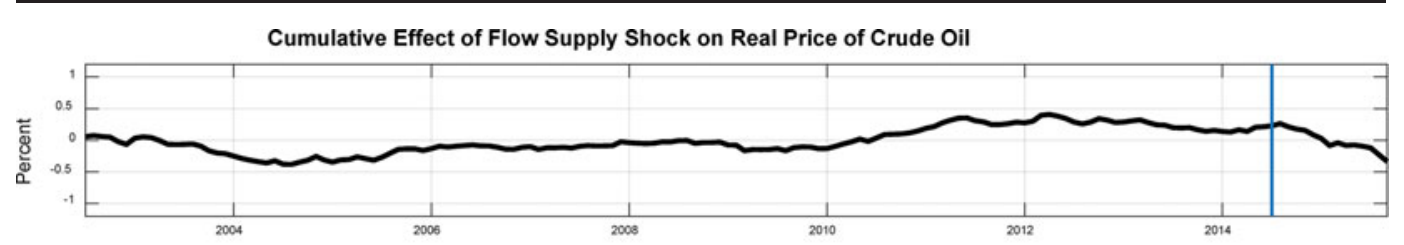

Cumulative Effect of Flow Demand Shock on Real Price of Crude Oil

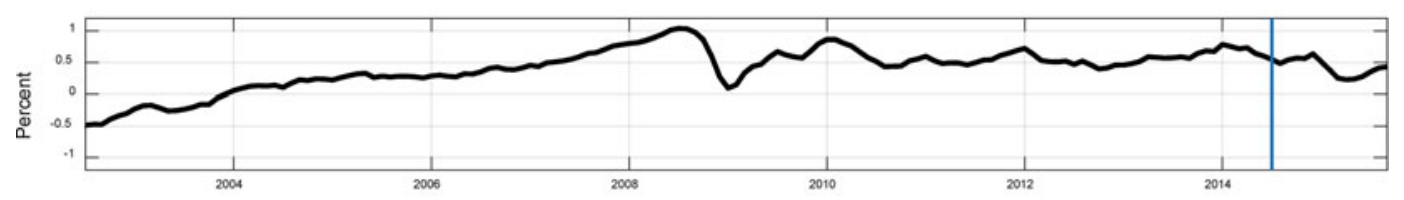

Cumulative Effect of Speculative Demand Shock on Real Price of Crude Oil

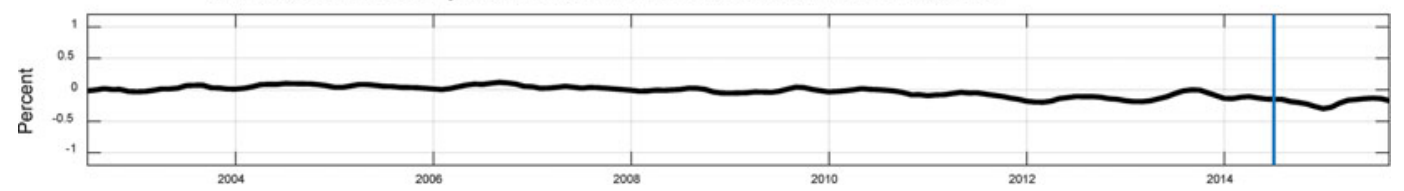

Notes: The underlying structural model is constructed as in Kilian and Lee (2014), except for the fact that the estimation sample has been updated to August 2015. The real price of oil is expressed in percent deviations from the long-run average real price of crude oil. Each subplot shows the extent to which the shock in question moved the real price of oil up or down since 2003. The vertical lines mark the beginning of the oil price decline of 2014-15.

counterfactual compared with the actual price of oil. A more detailed discussion of this procedure can be found in Appendix B.

Figure 7 shows two measures of the counterfactual path of world oil production corresponding to competing views of how large world oil production would have been in the absence of the U.S. fracking boom. The indirect measure in the left panel is derived from the effects of fracking on international trade in crude oil. This measure consists of the reduction in U.S. crude oil imports from the rest of the world and the crude oil equivalent of the increase in U.S. exports of refined products, adjusted for net increases in U.S. crude oil imports from Canada, Mexico, and Venezuela, as discussed in sections 3 and 4. The direct measure in the right panel is based on the change in shale oil production since November 2008, as discussed in section 2. As noted earlier, the indirect measure is slightly larger than the direct measure, but the overall pattern is similar. One potential difference is that increased shale oil production need not translate to increased production of refined products within the same month, given bottlenecks in the shipping of this oil to U.S. refineries. Instead it may be accumulated in inventories and potentially refined at a later point (see Kilian 2016). The indirect measure accounts for this problem and hence may be more reliable. It may involve other approximation errors, however, that do not arise when constructing the direct measure.

\subsection{The Counterfactual Oil Supply Shock Sequences}

Given the change in the quantity of oil produced in equilibrium under the counterfactual, it is straightforward to infer how much the supply curve must shift each month, conditional on past data, in order to produce the counterfactual equilibrium quantity. Figure 8 shows the sequence of flow supply shocks that would have to be imposed in the global oil market model of Kilian and 
Figure 7: Alternative Counterfactuals for World Oil Production in the Absence of the U.S. Fracking Boom
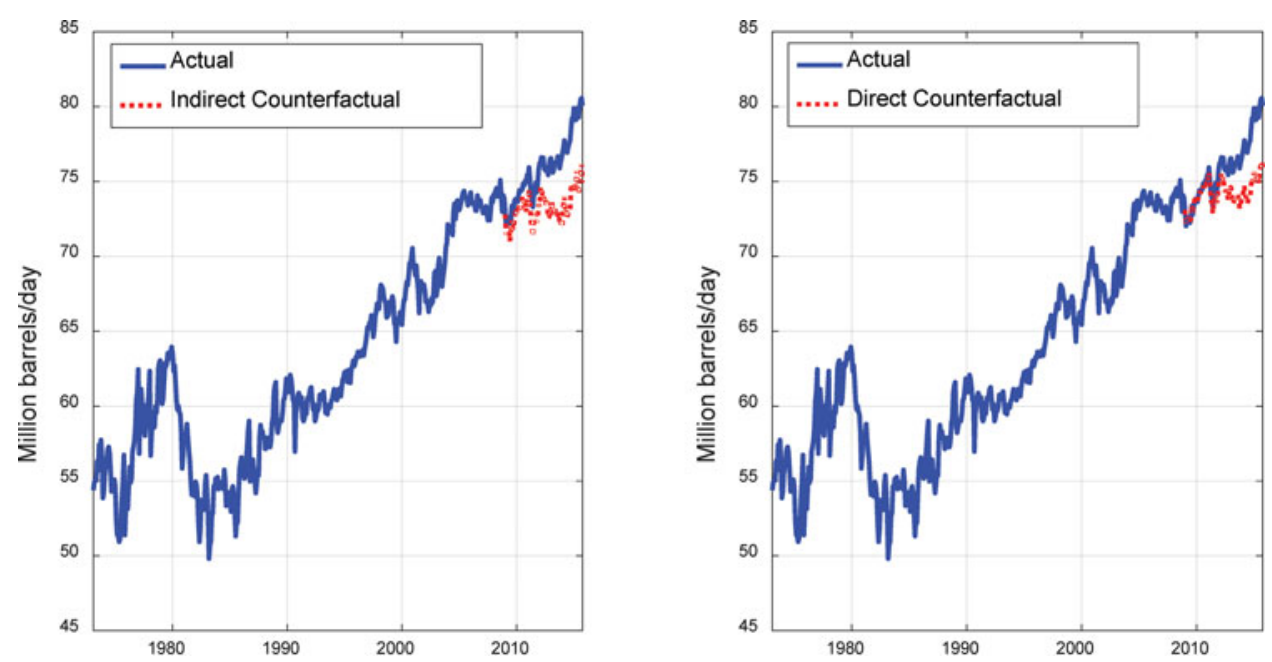

Notes: The indirect counterfactual is based on the reduction in U.S. crude oil imports from the rest of the world and the crude oil equivalent of the expansion of U.S. exports of refined products, adjusted for the net increase in U.S. crude oil imports from Canada, Mexico, and Venezuela, which represents primarily an influx of heavy crudes unrelated to fracking. The direct counterfactual is based on the change in U.S. shale oil production since 2008.11, as shown in the right panel of Figure 1.

Figure 8: Sequence of Flow Supply Shocks Required to Implement the Alternative Counterfactuals in Figure 7
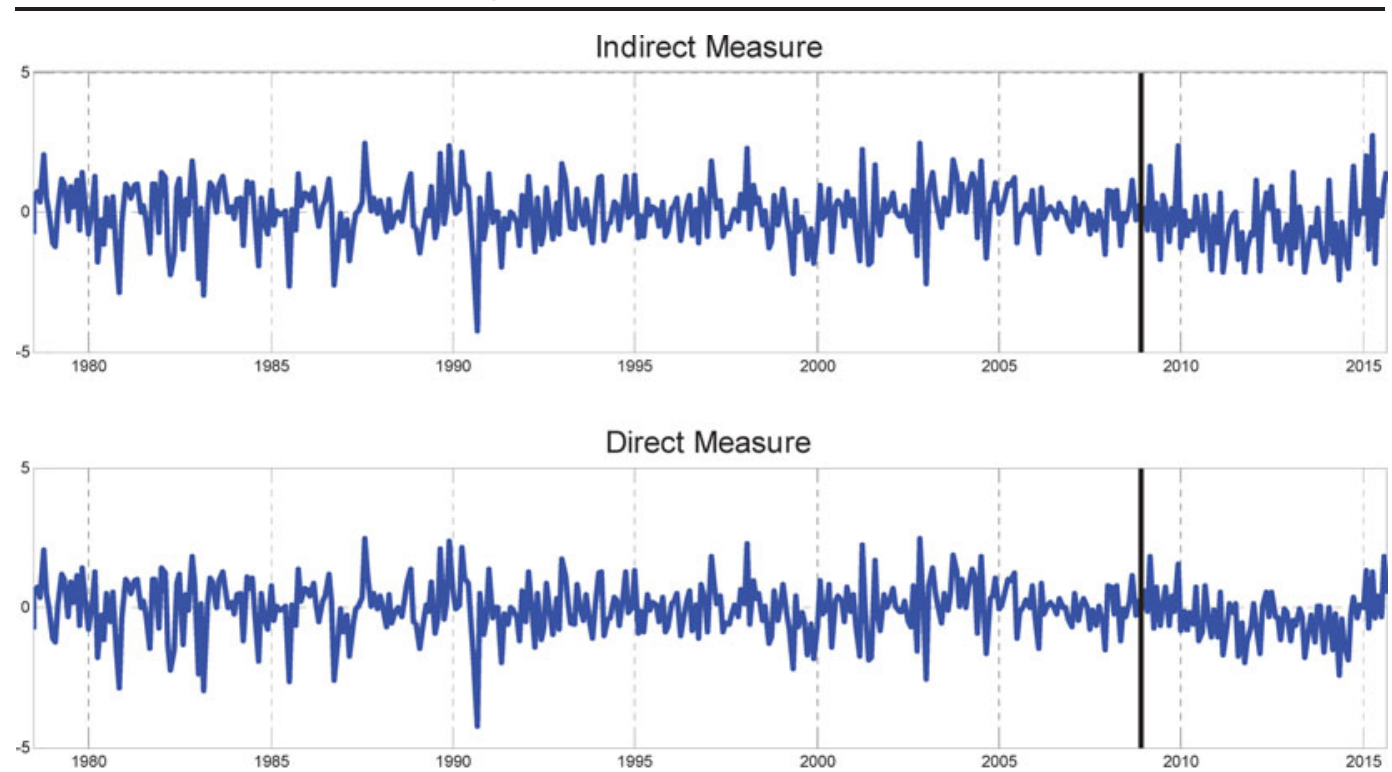

Notes: Computations by the author based on the algorithm described in Appendix B. The vertical line marks the beginning of the counterfactual in December 2008. 


\section{Figure 9: The Impact of Shale Oil Production on the Brent Price of Crude Oil}
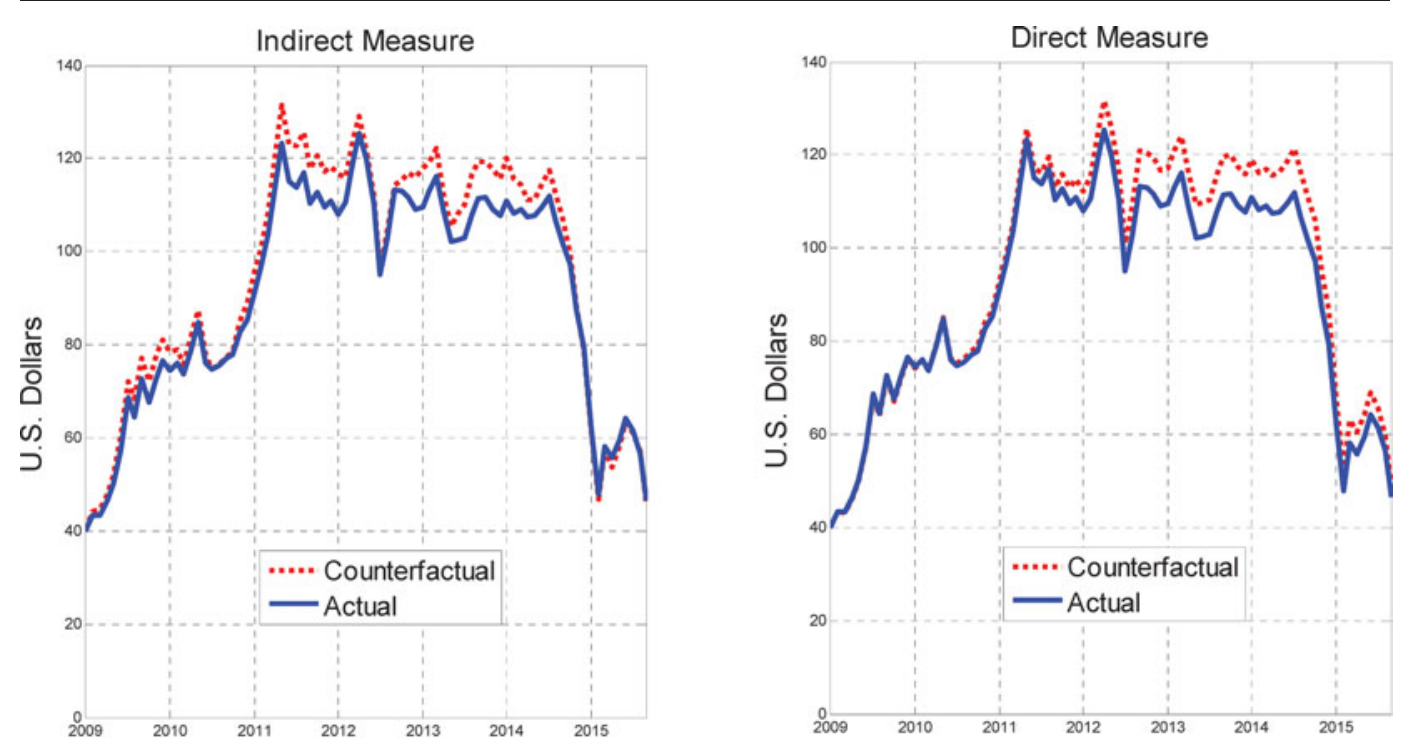

Notes: The counterfactual path for the nominal Brent price of crude oil inferred from the two counterfactuals in Figure 7 , as discussed in Appendix B.

Lee (2014) to make global oil production follow the counterfactual path of world oil production in Figure 7. An important concern is whether the flow supply shocks required to implement the prespecified path of global oil production after November 2008 are too large by historical standards or too predictable to maintain the assumption of a time-invariant structural VAR model. Figure 8 illustrates that neither of these shock sequences involves shocks that are unusually large by historical standards, addressing the first concern. As to the second concern that the counterfactual shocks must not be predictable, it is useful to focus on evidence of a large number of consecutive flow supply shocks having the same sign (referred to as a "run"). In the upper panel the longest run observed after December 2008 is seven months. Runs of this length are not unprecedented. The longest run prior to December 2008, in fact, lasts nine months. Thus runs in the flow supply shock data are neither particularly unusual nor do they necessarily imply that market participants would have found it easy to anticipate these shocks. Rather their existence is consistent with the view that the rapidly increasing growth rate of shale oil production continued to surprise market participants more often than not. The corresponding shock sequence in the lower panel of Figure 8, in contrast, exhibits one run lasting for fourteen months, which is considerably longer than the longest run in the historical data, but similar runs are not unprecedented in other structural shock sequences in this model and in the literature more generally. ${ }^{13}$

\subsection{How Much Higher the Brent Price Would Have Been Under the Counterfactuals}

Figure 9 plots the Brent price of crude oil in U.S. dollars $\left(P_{t}^{\text {actual }}\right)$ along with the counterfactual evolution of the Brent price $\left(P_{t}^{\text {counterfactual }}\right)$ based on these shock sequences. These estimates

13. In a related context, Kilian and Hicks (2013) documented prediction errors in professional global real GDP growth forecasts of the same sign for nearly five years during 2003-08. As long as such patterns average out in the long run, they do not violate the premise of rational expectations. 
are obtained based on counterfactual simulations of the log of the real price of oil in the global oil market model discussed earlier, estimated on data until August 2015. The simulated oil price data have been adjusted for differences between the Brent price and the U.S. refiners' acquisition cost for crude oil imports. The Brent price of crude oil may be interpreted as a proxy for the global price of crude oil. The left panel of Figure 9 shows that under the indirect measure of the counterfactual evolution of world oil production the Brent price of oil would have been higher by as much as $\$ 5$ in 2009, but most of the cumulative effects of the fracking boom would have been observed between 2011 and mid-2014, with the counterfactual price exceeding the actual Brent price by as much as $\$ 9$ at times. Thereafter, the price differential $P_{t}^{\text {counterfactual }}-P_{t}^{\text {actual }}$ becomes negligible again. This decline can be traced to the fact that the growth rate of shale oil production slowed unexpectedly in 2014 and 2015. In contrast, under the direct measure of the counterfactual evolution of world oil production the Brent price of oil would have been largely the same as the actual price until late 2010, as shown in the right panel of Figure 9. Between 2011 and mid-2014, the Brent price of oil would have been higher by as much as $\$ 10$ in the absence of the U.S. fracking boom, reaching $\$ 120$ repeatedly and at some point even $\$ 130$. Unlike in the first counterfactual, even in 2015 , the Brent price would have been higher than actually observed price by as much as $\$ 5 .^{14}$

The estimates in Figure 9 also shed light on the extent to which the U.S. fracking boom caused the decline in the global price of crude oil in late 2014 and early 2015 . Both counterfactuals agree that in the absence of the fracking boom this oil price decline would have occurred at the same time, as it did, but that it would have started at a higher level. According to Figure 9, the cumulative decline in the Brent price would have been $\$ 70$ under both specifications of the counterfactual (and therefore would have been $\$ 6$ higher than in the actual data). Thus, there is no support for the view that U.S. fracking was the primary cause of this specific oil price decline. This result complements the analysis in Baumeister and Kilian (2016b) who were unable to pin down the quantitative role of fracking specifically, but who provided evidence that a slowdown in the global demand for oil was a major contributor to this specific oil price decline in addition to a mix of shocks to actual and/or expected global oil supplies prior to July 2014 and a shift in oil price expectations in July 2014. Figure 9 helps refine that interpretation. It also complements the analysis of the cumulative impact of all global oil supply shocks combined in Figure 6 based on the structural model of Kilian and Lee (2014).

\subsection{Choosing Among the Two Counterfactuals}

The first two panels of Figure 10 show the price differentials $P_{t}^{\text {counterfactual }}-P_{t}^{\text {actual }}$ obtained from Figure 9 under each of the two alternative counterfactuals. It highlights that only the indirect measure implies a positive price differential during 2009 and early 2010, whereas only the direct measure implies a positive price differential after late 2014, raising the question of which of these price differentials is economically more plausible. This question may be assessed based on the information in the bottom panel of Figure 10, which plots the dollar spread between the Brent price and the West Texas Intermediate (WTI) price of crude oil. ${ }^{15}$ This spread conveys important information about when the fracking boom began to affect the U.S. market for crude oil.

14. The order of magnitude of the estimated cumulative effects seems reasonable in light of historical evidence on the effect of oil supply shocks. When the Iran-Iraq War broke out in late 1980, about $4 \%$ of world oil production was removed from the market, followed by approximately a $10 \%$ increase in the price of crude oil. U.S. shale oil production amounts to an increase of about $4 \%$ in global crude oil production, as shown in Kilian (2016), and hence would be expected to be associated with a fall in the price of oil of about $10 \%$, which amounts to about $\$ 10$ per barrel.

15. The Brent price refers to the spot price of light sweet crude oil traded in London, UK, whereas the WTI price is the spot price of light sweet crude oil for delivery in Cushing, OK. 


\section{Figure 10: Brent Oil Price Differentials}
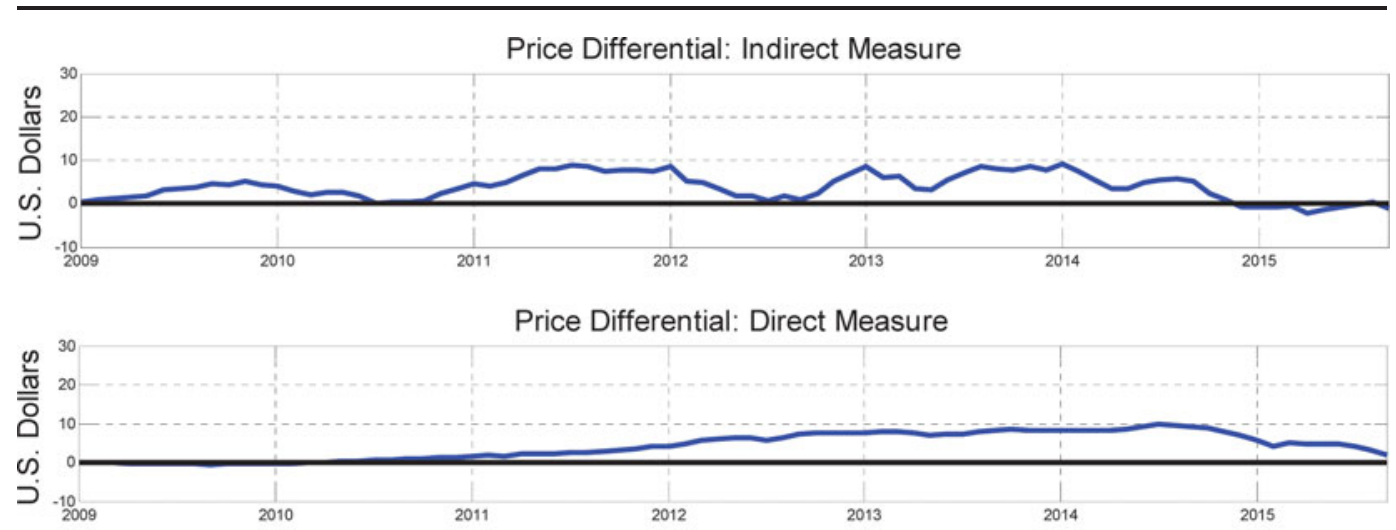

Brent-WTI Price Differential

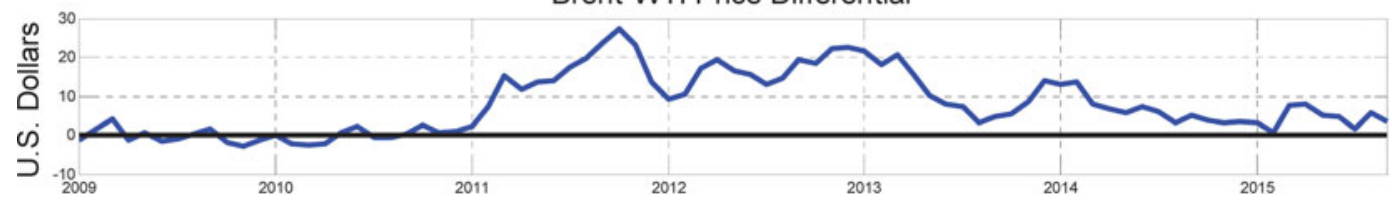

Notes: The first two panels are constructed from the counterfactual price paths for the Brent price in Figure 9. The third panel shows the spread between the Brent and WTI spot prices, as reported by the EIA.

The fact that the Brent-WTI spread only widened in late 2010 suggests that the positive price differential during 2009 and early 2010 in the first panel cannot be attributed to the fracking boom, casting doubt on the indirect counterfactual. As discussed in Kilian (2016), traditionally these crude oil prices have been closely tracking one another. This pattern only changed when the U.S. tight oil boom created a glut of crude oil in the central United States, causing WTI oil to trade at a discount relative to the global price for oil, as measured by the Brent price. We know that the initial drop in the WTI price relative to the Brent price occurred because there was not enough transportation capacity to ship the crude oil arriving from the Bakken and other shale oil plays in large enough quantities from Cushing to refiners elsewhere in the United States. As a result, most U.S. refiners, including the refiners along the Gulf Coast and the East Coast, continued to rely on oil imports at this stage (see Kilian 2016). Nor were U.S. refiners able to take advantage of the glut of oil in Cushing to increase exports of refined products. These transportation bottlenecks loosened only gradually over time, as rail, barge and pipeline capacity increased. There are of course shale oil plays such as Eagle Ford in Texas with easier access to refineries in the Houston area and beyond, but production in Eagle Ford was negligible prior to 2011. Given that neither of the two mechanisms by which shale oil production affects the global price of oil were in operation at this stage of the shale oil boom, it would be unreasonable to expect shale oil production to have had a large effect on the global price of crude oil before $2011 .{ }^{16}$ In short, the evolution of the Brent-WTI

16. It is important to stress that the Brent-WTI price differential does not by itself represent a proper counterfactual for the global price of oil because an increase in tight oil production all else equal will have a larger effect on the U.S. price of oil than on the global price. All we can say is that if there is no effect on the U.S. price of oil until late 2010, then fracking is unlikely to have affected the global price before this point in time. 


\section{Figure 11: Saudi Oil Revenue Losses Under the Direct Measure of the Counterfactual}


Notes: The plot in the lower panel expresses the reduction in Saudi oil revenues caused by the fracking boom as a fraction of Saudi oil revenue in November 2008, when the Brent price of oil stood at \$52.45. For example, at its peak in 2014 the oil revenue loss amounted to $20 \%$ of the Saudi oil revenue of November 2008.

spread supports the conclusion that the price differential in the second panel based on the direct measure of the counterfactual is a more accurate approximation. The remainder of the analysis therefore focuses exclusively on the latter counterfactual. ${ }^{17}$

\subsection{Implications for Saudi Oil Revenues}

The sequence of price differentials $P_{t}^{\text {counterfactual }}-P_{t}^{\text {actual }}$ may be used to compute, month by month from December 2008 until August 2015, the additional revenue Saudi Arabia would have received after November 2008 in the absence of the U.S. fracking boom, given the historically observed levels of Saudi oil production. The upper panel of Figure 11 shows the evolution of the losses in Saudi oil revenue measured in billions of U.S. dollars under the preferred counterfactual based on the direct measure of tight oil production. There is evidence that the Saudi oil revenue losses were negligible initially, but gradually increased over time, reaching 2 billion dollar per month in late 2012 and peaking at 2.9 billion dollars per month in mid-2014, before levelling off.

17. One may be concerned that the model-based results in Figure 10 are driven primarily by the choice of the price elasticity of oil demand. This is not the case. It can be shown that the overall pattern of the cumulative effect of the shale oil revolution on the Brent price of oil is the same for all reasonable elasticity values. The cumulative effect on the price of oil rises starting in 2011, peaks by mid-2014 and drops thereafter. In no case is shale oil an important factor in driving the oil price decline in the second half of 2014. Although there is no monotonic relationship between this elasticity and the impact of the U.S. shale oil boom on the price of oil, it is difficult to generate much larger cumulative effects for reasonable elasticity values. For example, the cumulative effect on the Brent price is bounded by $\$ 6.54 /$ barrel for an elasticity of -0.21 and by $\$ 3.86 /$ barrel for an elasticity of -0.31 , compared with $\$ 9.74 /$ barrel in the baseline model. For an elasticity of -0.11 , outside of the range of reasonable values, the effect rises to $\$ 14.59 /$ barrel, but the pattern remains similar. 
Of course, this evidence does not speak to the overall loss of Saudi oil revenue following the decline in the price of oil after June 2014, but only to the component of this loss caused by the U.S. fracking boom. It should also be noted that the dip in Saudi oil revenue losses in January 2015 mirrors the temporary tightening of the Brent-WTI spread, adding credibility to this estimate.

A rough measure of the cumulative impact of the fracking boom on Saudi Arabia is obtained by simply cumulating these losses. The cumulative decline in Saudi oil revenue between December 2008 and August 2015 is 102.1 billion dollars. This amounts to an average loss per month of 1.3 billion U.S. dollars. The incremental Saudi oil revenue losses between July 2014, when the price of oil began to fall precipitously, and August 2015 are 24.3 billion dollars. To put these estimates in perspective, the lower panel of Figure 11 expresses the reduction in Saudi oil revenues caused by the fracking boom as a percentage of the Saudi oil revenue in November 2008, when the Brent price of oil stood at \$52.45. It is important to be clear about the interpretation of this estimate. Figure 11 shows that in mid-2014, for example, Saudi Arabia in the absence of the U.S. fracking boom would have earned $120 \%$ of the oil revenue it generated in November 2008, if it had produced exactly as much oil as it actually did in mid-2014. ${ }^{18}$

\section{A CASE STUDY OF SAUDI ARABIA}

Saudi Arabia's strategy for dealing with the fracking boom so far has been to preserve its market share and to avoid idle capacity (see, e.g., Fattouh and Sen 2015; Fattouh, Poudineh and Sen 2015). There is no sign of Saud Arabia having curtailed its oil production nor is it likely that a unilateral strategy of restricting Saudi oil production would have helped preserve Saudi oil revenue (see Baumeister and Kilian 2016b). Instead, the Saudi government has dealt with the decline in its oil revenue mainly by tapping its financial reserves, as predicted by standard models of precautionary savings (see, e.g., Bems and de Carvalho Filho 2011). IMF data show a reduction in Saudi net foreign asset holdings of near $\$ 90$ billion between mid-2014 and August 2015. This estimate is considerably larger than the loss in oil revenue over the same period that is attributable to the fracking boom. The latter I estimated to be about $\$ 24$ billion. In other words, the analysis in this article tentatively suggests that in the absence of the fracking boom the reduction in Saudi foreign exchange reserves since mid-2014 would have been about two thirds of the actual decline. The decline not explained by the fracking boom reflected higher crude oil production elsewhere in the world, shifts in oil price expectations affecting the demand for oil stocks, and the effects of a slowing global economy.

An important question is how long Saudi Arabia can sustain such losses in its foreign exchange reserves. If the decline in Saudi net foreign assets were to continue at the rate experienced

18. It should be kept in mind that this estimate is only an approximation, first, because Saudi oil exports that were diverted from the United States to Asian economies, for example, were not necessarily priced based on the Brent benchmark, and, second, because my methodology abstracts not only from changes in Saudi oil production, but also from any Saudi efforts to market its oil more aggressively. With regard to the first point, my analysis assumes that the price of Saudi crude oil declined as much as the price of Brent crude, allowing for differences in the level of these prices. My analysis also abstracts from differences between Saudi exports of heavy and light crude oil. The concern is not so much that Saudi Arabia could have substituted exports of heavy crude to the United States for its exports of light crude. This possibility seems unlikely because, as I showed, imports of lower-priced Canadian heavy crudes increasingly substituted for U.S. imports of heavy crudes from other sources, at the same time as shale oil production displaced U.S. imports of light sweet crude oil. Rather the concern is that by applying the counterfactual price differential indiscriminately to Saudi production of light and heavy crude oil, one overestimates the loss in oil revenue that can be attributed to shale oil because shale oil competes with Saudi heavy crude oil only indirectly through U.S. exports of refined products.

Copyright (C) 2017 by the IAEE. All rights reserved. 
between January 2015 and January 2016, one would expect Saudi net foreign assets to be exhausted by early 2020. Of course, this process would accelerate if the price of oil were to fall further, or it would slow if the price were to recover somewhat. There are two potential mitigating factors, however. First, unlike some of its neighbors, Saudi Arabia has very little external debt because it resisted the temptation to leverage its increased oil revenues during the 2003-08 oil price boom by running up external debt (see Tornell and Lane 1998). As a result, for now, the Saudi government has been able to borrow in global financial markets, given the expectation that the price of oil will ultimately recover. Second, the Saudi government thus far has been reluctant to impose fiscal retrenchment, because of the political costs of such measures, but in December 2015 it announced a budget plan that envisions cuts in spending from $\$ 975$ billion in 2015 to $\$ 840$ billion in 2016 (representing a 14\% drop in government spending). The finance ministry also announced that it would raise taxes and adjust subsidies for water, electricity and petroleum products over the next five years.

The central question for Saudi Arabia is to what extent it should rely on external borrowing and to what extent it should cut fiscal spending. Economic theory tells us that it makes sense for Saudi Arabia to borrow in response to a short-lived fall in oil prices. If the decline in the price of oil were expected to persist for a long time, in contrast, external borrowing would not be the appropriate response and the adjustment instead would have to come from fiscal retrenchment. Thus, the answer to the question of how much fiscal adjustment Saudi Arabia requires is ultimately determined by how long one expects low oil prices to persist. How soon the price of oil is expected to recover depends in important part on why the price of oil declined and how important these determinants will remain in the future (see Baumeister and Kilian 2016b).

For example, to the extent that this price decline was caused by the U.S. fracking boom, the question is how long this boom can persist at current prices with many commercial tight oil producers already experiencing heavy operating losses, and how quickly these firms could resume tight oil production at higher oil prices, if they were forced to close down. The same concern applies to unconventional oil production in Canada. Even if the current low price of oil were to put shale oil producers out of business, an obvious concern would be that shale oil production is likely to resume as soon as world oil prices recover sufficiently, as long as there remains easily accessible shale oil in the ground. At $\$ 60$ per barrel, for example, many U.S. shale oil producers are likely to generate profits, even if they do not at $\$ 40$ per barrel. If we accept this reasoning, we should treat much of the shale oil component of the Saudi foreign exchange losses as persistent and respond by cutting Saudi fiscal spending rather than borrowing.

Of course, shale oil is only one reason for the ample supply of crude oil in world markets. To the extent that other oil producers including Russia and Iraq have expanded oil production in recent years, or, as in the case of Iran, are about to do so, the question becomes one of how long state-controlled oil producers with few other options to generate foreign exchange and no accountability to shareholders or financial markets will put pressure on the price of oil. Countries such as Russia, for example, rely on oil revenue to sustain their economy. There is no reason to expect these countries to reduce their exports, except to the extent that inadequate investment in the oil sector limits their ability to sustain high levels of oil production in the long run.

One countervailing force on the supply side is that production in many other oil-producing countries will continue to fall over time, as conventional fields are depleted. The United Kingdom and Norway are good examples. There also examples of oil producers such as Mexico, where mismanagement has made oil production too costly to compete in global markets. These high costs in conjunction with low investment have slowed Mexican oil production. Table 1 documents that 
world oil production has not grown nearly as fast, as might have been suggested by news reports about rising oil production in selected countries. The simultaneous gradual decline in oil production elsewhere in the world has largely gone unreported. Over time one would expect these continued production declines to make room for higher oil production in countries such as Iraq, Iran, Saudi Arabia, Russia, or the United States. The problem from Saudi Arabia's point of view is that there is a good chance that this process may take longer than its net foreign assets will last.

One would, in fact, expect this gradual decline in global oil production to be accelerated by the current worldwide cutbacks in investment in oil exploration and new oil fields. As a result, it would be surprising if the price of crude oil did not recover somewhat over the next few years. Just how far this cyclical effect will push up the price of oil and how soon is less clear, however. It may easily take another year or two for these effects to become quantitatively important. Moreover, a partial recovery of the global price of crude oil to $\$ 65$ per barrel in, say, two years would still leave the Saudi economy facing a substantial shortfall compared with prices near $\$ 110$ per barrel prior to July 2014.

The demand side of the oil market also plays an important role in assessing the persistence of the current oil price slump. To the extent that low oil prices in part reflect a sluggish global economy, as documented in Baumeister and Kilian (2016b), the question becomes at what point emerging Asia, Japan, and Europe, in particular, will recover. A swift and sustained global economic recovery, unlikely as it may seem at this point, would quickly eliminate the current glut of crude oil. All indications are, however, that there remains considerable downside risk in the global economy and that the global recovery, when it starts, will be slow and gradual. One would not expect the demand for oil to surge in the foreseeable future.

A final remedy may seem to be coordinated oil supply cuts, which helped alleviate the glut of crude oil in 1998, when the price of oil dropped to \$11 (see Kilian and Murphy 2014). That solution seems unlikely in the current environment of low demand for oil, however, if we take the theory of cartels as a guide. Oil cartels are inherently procylical and tend to fall apart during economic slumps (see Barsky and Kilian 2002). In September 2016, OPEC announced a tentative agreement including Iran about setting an OPEC production target. The all-important question of exactly how much production to cut and how to allocate these production cuts among the OPEC member countries was deferred to the next meeting in November 2016. This is not the first time that OPEC has discussed restricting oil production.

Most recently, talks between Venezuela, Saudi Arabia, Russia and other oil producers about coordinated supply restrictions in April 2016 collapsed within days. One reason was that the United States, Iran and Iraq were unlikely to feel bound by any such agreements. Without the cooperation of non-OPEC oil producers such as Russia and the United States, any OPEC agreement is bound to come under pressure. Moreover, even if an agreement were ultimately announced in November 2016, the experience of the 1980s shows that OPEC members have routinely cheated on their production quotas, when faced with a weak economy and strong revenue needs. Thus, the current agreement is unlikely to be implemented successfully. In the meantime, the cheap talk by OPEC about future production cuts has pushed up the price of oil by several dollars, alleviating some of the fiscal pressure associated with low oil prices. In the absence of decisive action in November, this increase is likely to dissipate. Moreover, relative to the magnitude of the earlier price decline, this increase has been only modest.

There is little doubt that the price of oil will recover in the longer run, but the question is whether Saudi net foreign assets can sustain the Saudi economy until then. It is more than likely that the Saudi economy could face another three or four lean years, at which point the precautionary 
savings in the Saudi sovereign wealth fund would likely be exhausted, while the prospects of new external borrowing would diminish. Already, the Saudi credit rating has been lowered. Thus, there appears to be no alternative to some considerable measure of fiscal retrenchment in the foreseeable future. The same argument applies even more forcefully to other Arab oil producers faced with more foreign debt and lower foreign exchange reserves.

\section{CONCLUDING REMARKS}

My analysis highlighted the need for far-reaching reforms in Arab oil-producing countries. A natural starting point for such reforms would be for policymakers to reduce or even phase out domestic subsidies on energy consumption. In fact, implementing such reforms is likely to be easier politically in an environment of falling oil prices. The United Arab Emirates, for example, have already successfully aligned their domestic fuel prices with prices in global markets. Many other Arab oil producers have yet to implement similar reforms. Clearly, however, such reforms will not be enough, given the magnitude of the oil revenue shortfall that has accumulated in recent years. There will have to be more fundamental changes to the welfare state in countries such as Saudi Arabia and implementing these changes will be politically challenging. One problem is that many Arab oil producing countries lack an income tax base. Taxing incomes of domestic citizens working in the public sector would be the same effectively as lowering public wages and hence fiscal spending, leaving taxes on foreign workers' income as the only policy option for raising tax revenue. Thus, much of the fiscal adjustment will have to occur on the expenditure side. It seems safe to conclude that an extended period of low oil prices is likely to cause far-reaching economic changes in Arab oil-producing countries as well as changes in the social fabric, whether these changes are implemented gradually in anticipation of growing financial constraints or are eventually forced by external events. The obvious concern is that, if this transition is not managed well, geopolitical risks in the Middle East, which have not played a large role since 1990, may become much more important again, contributing to higher oil prices in the long run. One indication that this concern is taken seriously by policymakers in the Arab world is that Saudi Arabia in June 2016 unveiled a plan to more than triple its non-oil revenue by 2020, while reducing public spending. This plan includes the introduction of indirect taxes as well as reductions in subsidies for water and electricity and public wage cuts.

\section{ACKNOWLEDGMENTS}

I thank Christiane Baumeister, Bassam Fattouh, Ryan Kellogg, Charles Mason, the editor and three anonymous referees for helpful comments and discussion. This work has benefited from a financial grant from the Economic Research Forum and from additional comments by two anonymous referees provided by the Forum. The contents and recommendations do not necessarily reflect the views of the Economic Research Forum.

\section{REFERENCES}

Barsky, R.B. and L. Kilian (2002). "Do We Really Know that Oil Caused the Great Stagflation? A Monetary Alternative." In B. Bernanke and K. Rogoff, eds., NBER Macroeconomics Annual 2001. pp. 137-183.

Baumeister, C. and L. Kilian (2014). "Real-Time Analysis of Oil Price Risks using Forecast Scenarios." IMF Economic Review 62: 119-145. https://doi.org/10.1057/imfer.2014.1.

Baumeister, C. and L. Kilian (2016a). "Forty Years of Oil Price Fluctuations: Why the Price of Oil May Still Surprise Us." Journal of Economic Perspectives 30: 139-160. https://doi.org/10.1257/jep.30.1.139. 
Baumeister, C. and L. Kilian (2016b). "Understanding the Decline in the Price of Oil since June 2014." Journal of the Association of Environmental and Resource Economists 3: 131-158. https://doi.org/10.1086/684160.

Baumeister, C. and L. Kilian (2017). "Lower Oil Prices and the U.S. Economy: Is This Time Different?" Forthcoming: Brookings Papers on Economic Activity.

Baumeister, C. and G. Peersman (2013). "The Role of Time-Varying Price Elasticities in Accounting for Volatility Changes in the Crude Oil Market." Journal of Applied Econometrics 28: 1087-1109. https://doi.org/10.1002/jae.2283.

Bems, R. and I. de Carvalho Filho (2011). "The Current Account and Precautionary Savings for Exporters of Exhaustible Resources.” Journal of International Economics 84: 48-64. https://doi.org/10.1016/j.jinteco.2011.02.004.

Benes, J., M. Chauvet, O. Kamenik, M. Kumhof, D. Laxton, S. Murula and J. Selody (2015). "The Future of Oil: Geology versus Technology." International Journal of Forecasting 31: 207-221. https://doi.org/10.1016/j.ijforecast.2014.03.012.

Bodenstein M. and L. Guerrieri (2012). "On the Sources of Oil Price Fluctuations.” Working paper. Federal Reserve Board. Coglianese, J., L.W. Davis, L. Kilian and J.H. Stock (2017). "Anticipation, Tax Avoidance, and the Price Elasticity of Gasoline Demand." Forthcoming: Journal of Applied Econometrics.

Fattouh, B. (2014). "The U.S. Tight Oil Revolution and its Impact on the Gulf Cooperation Council Countries: Beyond the Supply Shock." OIES Paper WPM 54, Oxford University.

Fattouh, B. and A. Sen (2015). "Saudi Arabia Oil Policy: More than Meets the Eye?" OIES Paper MEP 13, Oxford University.

Fattouh, B., R. Poudineh and A. Sen (2015). "The Dynamics of the Revenue Maximization-Market Share Trade-Off: Saudi Arabia's Oil Policy in the 2014-2015 Price Fall” OIES Paper WPM 61, Oxford University.

Holland, S.P. (2008). "Modeling Peak Oil," The Energy Journal 29(2): 61-80. https://doi.org/10.5547/ISSN0195-6574-EJVol29-No2-4.

Holland, S.P. (2013). “The Economics of Peak Oil.” In J.F. Shogren, ed., Encyclopedia of Energy, Natural Resource, and Environmental Economics, Vol. 1, Amsterdam: Elsevier. pp. 146-150. https://doi.org/10.1016/B978-0-12-3750679.00124-8.

Kilian, L. (2009). "Not All Oil Price Shocks Are Alike: Disentangling Demand and Supply Shocks in the Crude Oil Market." American Economic Review 99: 1053-1069. https://doi.org/10.1257/aer.99.3.1053.

Kilian, L. (2016). "The Impact of the Shale Oil Revolution on U.S. Oil and Gas Prices." Review of Environmental Economics and Policy 10: 185-205, Summer 2016. https://doi.org/10.1093/reep/rew001.

Kilian, L. and B. Hicks (2013). "Did Unexpectedly Strong Economic Growth Cause the Oil Price Shock of 2003-2008?" Journal of Forecasting 32: 385-394.. https://doi.org/10.1002/for.2243.

Kilian, L. and D.P. Murphy (2014). "The Role of Inventories and Speculative Trading in the Global Market for Crude Oil." Journal of Applied Econometrics 29: 454-478. https://doi.org/10.1002/jae.2322.

Kilian, L. and T.K. Lee (2014). "Quantifying the Speculative Component in the Real Price of Oil: The Role of Global Oil Inventories.” Journal of International Money and Finance 42: 71-87. https://doi.org/10.1016/j.jimonfin.2013.08.005.

Kleinberg, R.L., S. Paltsev, C.K. Ebinger, D. Hobbs and T. Boersma (2016). "Tight Oil Development Economics: Benchmarks, Breakeven Points, and Inelasticities.” MIT CEEPR Working Paper No. 2016-12.

Serletis, A, G. Timilsina and O. Vasetsky (2010).”International Evidence on Sectoral Interfuel Substitution.” The Energy Journal 31(4): 1-29. https://doi.org/10.5547/ISSN0195-6574-EJ-Vol31-No4-1.

Tornell, A. and P. Lane (1998). "Are Windfalls a Curse? A Non-Representative Agent Model of the Current Account." Journal of International Economics 44: 83-112. https://doi.org/10.1016/S0022-1996(97)00016-0.

U.S. Energy Information Administration (2015). Monthly Energy Review. December.

U.S. Energy Information Administration (2016). Drilling Productivity Report. January.

Waggoner, D.F. and T. Zha, (1999). "Conditional Forecasts in Dynamic Multivariate Models." Review of Economics and Statistics 81: 639-651. https://doi.org/10.1162/003465399558508. 


\section{APPENDIX A: RESPONSES OF THE GLOBAL OIL MARKET VAR MODEL VARIABLES TO EACH OF THE STRUCTURAL SHOCKS}
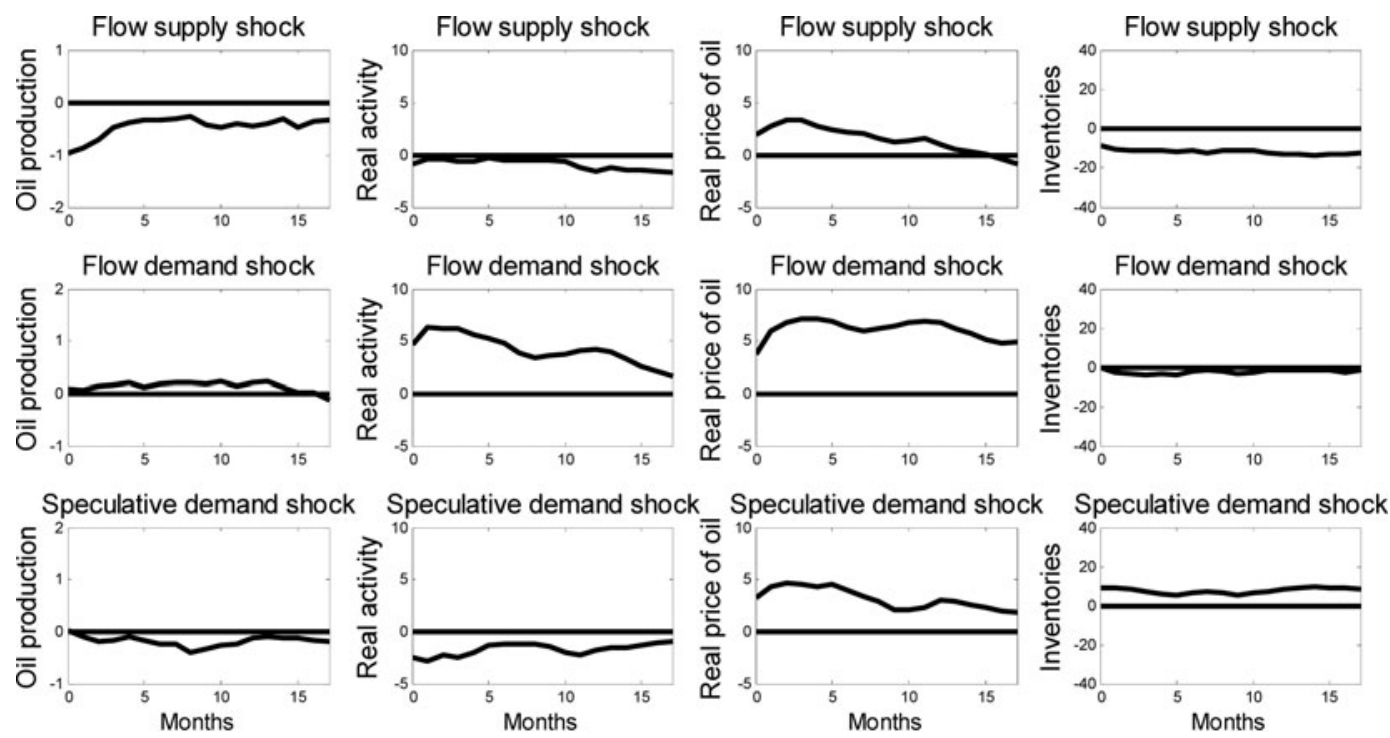

Notes: The underlying model is constructed as in Kilian and Lee (2014), except for the fact that the estimation sample has been updated to August 2015. All responses but the inventory responses are expressed in percentages. The inventory responses are in million barrels.

\section{APPENDIX B: CONSTRUCTING THE OIL PRICE SERIES UNDER THE COUNTERFACTUAL}

Let $y_{t}=\left(y_{1 t}, y_{2 t}, y_{3 t}, y_{4 t}\right)^{\prime}$ denote the vector of variables in the global oil market model of Kilian and Murphy (2014), where $y_{1 t}$ stands for the growth in world oil production and $y_{3 t}$ for the $\log$ of the real price of oil, in particular. Consider the structural VAR model

$$
B_{0} y_{t}=B_{1} y_{t-1}+\ldots+B_{24} y_{t-24}+w_{t}
$$

where the $4 \times 1$ vector $y_{t}$ is assumed to be stationary and the deterministic regressors have been suppressed for expository purposes. The assumption that the log real price of oil is stationary, in particular, is consistent with a range of evidence including the fact that this time series has not exhibited any apparent time trend over the estimation sample. The dimension of $B_{i}, i=0, \ldots, 24$ is $4 \times 4$. The $4 \times 1$ vector of structural shocks, $w_{t}=\left(w_{1 t}, w_{2 t}, w_{3 t}, w_{4 t}\right)^{\prime}$, where $w_{1 t}$ denotes a shock to the flow supply of crude oil, is assumed to be zero mean white noise with a diagonal $4 \times 4$ variancecovariance matrix $\Sigma_{w}$ that is of full rank and that without loss of generality can be normalized to equal the identity matrix. This structural model can be expressed in its reduced form as

$$
y_{t}=A_{1} y_{t-1}+\ldots+A_{24} y_{t-24}+u_{t}
$$

where $A_{i}=B_{0}^{-1} B_{i}, i=1, \ldots, 24$, and $u_{t}=B_{0}^{-1} w_{t}$ with variance-covariance matrix $\Sigma_{u}=B_{0}^{-1}\left(B_{0}^{-1}\right)^{\prime}$. Let the $4 \times 4$ matrix $\partial y_{t+i} / \partial w_{t}{ }^{\prime}=\Theta_{i}$ denote the responses of the model variables to each of the structural 
shocks at horizon $i=0,1, \ldots, H$. The matrix $\Theta_{i}=\left[\theta_{j k, i}\right]$ consists of elements $\theta_{j k, i}=\partial y_{j, t+i} / \partial w_{k t}$ that denote the response of variable $j$ to structural shock $k$ at horizon $i$. These responses may be computed as $\Theta_{i}=J \mathbf{A}^{i} J^{\prime} B_{0}^{-1}$, where $J=\left[\begin{array}{ll}I_{4} & 0_{4 \times 4(24-1)}\end{array}\right]$ and $\mathbf{A}$ denotes the matrix of slope parameters obtained by expressing the $\operatorname{VAR}(24)$ reduced-form model in its $\operatorname{VAR}(1)$ companion format.

In constructing the counterfactual in question, we make use of the fact that after removing the deterministic terms

$$
y_{t} \approx \sum_{i=0}^{t-1} \Theta_{i} w_{t-i}
$$

As a result, the fitted value for the log real price of oil can be written as

$$
\hat{y}_{3 t}=\sum_{j=1}^{4} \hat{y}_{3 t}^{(j)},
$$

where $\hat{y}_{3 t}^{(j)}$ denotes the cumulative contribution since the beginning of the sample of structural shock $j$ to the third model variable at time $t$, defined as

$$
\begin{aligned}
& \hat{y}_{3 t}^{(1)}=\sum_{i=0}^{t-1} \theta_{31, i} w_{1, t-i}, \\
& \hat{y}_{3 t}^{(2)}=\sum_{i=0}^{t-1} \theta_{32, i} w_{2, t-i}, \\
& \hat{y}_{3 t}^{(3)}=\sum_{i=0}^{t-1} \theta_{33, i} w_{3, t-i}, \\
& \hat{y}_{3 t}^{(3)}=\sum_{i=0}^{t-1} \theta_{34, i} w_{4, t-i} .
\end{aligned}
$$

Having simulated the posterior of the reduced-form model (2) obtained based on the full sample from February 1973 to August 2015, we recover estimates of $B_{0}^{-1}, \theta_{j k, i}$ and of $w_{t}=B_{0} u_{t}, t=$ $1, \ldots, T$, as in Kilian and Lee (2014) by selecting the posterior model with a short-run price elasticity of oil demand closest to the benchmark estimate of -0.26 in the literature.

In constructing the counterfactual, we retain the realizations of the flow supply shock $w_{1, t}$ up to November 2008, but we replace the estimates of $w_{1, t}$ for December 2008.12 through August 2015 by counterfactual values chosen to ensure that the path of world oil production corresponds to the counterfactual path shown in Figure 7. Given the demeaned growth rate of world oil production implied by the counterfactual, these values may be easily computed by an iterative procedure. Having computed what the expected value of $y_{1 t}$ given $\hat{y}_{1 t}^{(j)}, j=2,3,4$, would have been next month, if this month's supply shock had been zero, the difference between that model prediction and the target level of oil production growth, scaled by the impact response of world oil production to a flow supply shock, will be the magnitude of the flow supply shock, $w_{1 t}$, required to reach the growth target.

We then recompute $\hat{y}_{3 t}^{(1)}$ under the alternative sequence of flow supply shocks, while retaining the other three structural shock sequences as originally estimated in computing $\hat{y}_{3 t}^{(2)}, \hat{y}_{3 t}^{(3)}$ and $\hat{y}_{3 t}^{(4)}$. Given the implied sequence of $\hat{y}_{3 t}$, the corresponding sequence $P_{t}^{\text {counterfactual }}$ is constructed from the real price of Brent crude oil, scaled up by the percent deviation between the counterfactual real price of oil and the actual real price of oil in the model. The counterfactual real Brent price is converted back to dollars using the U.S. consumer price index. The price differential $P_{t}^{\text {counterfactual }}-P_{t}^{\text {actual }}$ for the remainder of the sample is obtained by subtracting the actual dollar price of Brent crude oil, $P_{t}^{\text {actual }}$, from $P_{t}^{\text {counterfactual }}$. 